Original Research Paper

\title{
Diversity Insects of Spring in Mutis Timau Nature Reserve, TTS District, NTT Province
}

\author{
Chatarina Gradict Semiun \& Gaudensius U. U. Boli Duhan \\ Biology Study Program Faculty of Science and Mathematics Widya Mandira Catholic University, \\ Kupang, Indonesia
}

\author{
Article History \\ Received : August $12^{\text {th }}, 2021$ \\ Revised : August $30^{\text {th }}, 2021$ \\ Accepted : September $10^{\text {th }}, 2021$ \\ Published : September $20^{\text {th }}, 2021$ \\ *Corresponding Author: \\ Chatarina Gradict Semiun, \\ Biology Study Program Faculty \\ of Science and Mathematics \\ Widya Mandira Catholic \\ University, Kupang, Indonesia \\ Email: gr4dict@gmail.com; \\ chatarinagr4dict@unwira.ac.id
}

\begin{abstract}
Insect diversity is believed to be used as a bio-indicator of spring quality, this study aimed at determining the spring insect diversity around the Mutis Timau Nature Reserve. The study was conducted from June to August 2019. Insects were caught by using the yellow pan trap and hand sorting. The diversity of spring insects was determined based on the Shannon-Wiener diversity index $\left(\mathrm{H}^{\prime}\right)$, species richness index (R1), species dominance index (D), and evenness index $(E)$. The results showed that 16 species belong to 11 families, and five orders of insects. The families included Gryllidae, Gryllotalpidae, Tetrigidae, Formicidae, Pompilidae, Apidae, Ochteridae, Veliidae, Hydrometridae, Nepidae, Coenagrionidae, Libellulidae, Carabidae, and Coccinellidae. The Shannon-Wiener species diversity index and the wealth index of the species of springs were classified as moderate $\left(\mathrm{H}^{\prime}=2.12\right.$ and $\left.\mathrm{R} 1=4.19\right)$. There was no type of spring insects dominated $(\mathrm{D}=0.23)$. All springs insects were found to have almost the same level of evenness $(E<1)$, with a value of 0.76 . Abiotic factors such as $\mathrm{pH}$ and soil temperature were within the tolerance range of spring insects.
\end{abstract}

Keywords: Insects diversity; Spring; Mutis Timau Nature Reserve

\section{Introduction}

The Mutis Timau Nature Reserve (MTNR) is part of the Timau Mutis forest group. This forest area is precisely located in Fatumnasi and Tobu Districts in TTS; Miomaffo Barat and Mutis TTU Districts (http://bbksdantt.menlhk.go.id). MTNR has a high potential for flora and fauna. One of them is the potential for the high diversity of arthropods such as insects. About $80 \%$ of animal species on earth are insects (Azmi et al., 2019). Almost all natural, modified, and terrestrial, and aquatic ecosystems support insect communities, including the aquatic insects around the MTNR area. Aquatic insects are a group of arthropods whose life cycle is part of the water. These insects play an essential-essential role in the food chain in an aquatic ecosystem. In aquatic ecosystems, insects play a role in the nutrient cycle and are an essential component of the food chain in the water (Hasan et al., 2016). Aquatic insects are found in almost all types of aquatic habitats such as lakes, fast river flows, very salty swimming pools, phytotelmata, coastal waters, and river estuaries, acid peat swamps, groundwater, hot springs, and even pools of crude oil seeping from the ground, and also in springs (Mohd et al., 2012).

Springs are crucial hydrological element of rivers and have significant ecological value as habitats with distinctive and naturally stable environmental conditions, and inhabited by distinctive fauna. The springs are unique and generally small, and very vulnerable to the anthropogenic transformations that have occurred in recent years in the ecological landscape, which have resulted in groundwater pollution and decreased quantity (Pakulnicika et al., 2016). As one of the most threatened ecosystems, the spring habitat has suffered from water quality damage due to river landscape modification for anthropogenic activities resulted in pollution. Some aquatic insect species are vulnerable and sensitive to environmental pollution, while others can live and reproduce in polluted water conditions (Popoola \& 
Otalekor, 2011). Thus, aquatic insects can be used as indicators to test water quality.

Freshwater insects are rarely investigated by scientists and conversions, even though they are important for comprehensively determining water quality combined with physic and chemistry aspects. They are important as environmental health biomonitoring (Nuraeni et al., 2019). Based on the survey result, the researchers found several villages in the vicinity of the MTNR area and the team chose Tunua and Fatumnasi villages as sampling locations as these two villages were closed to the nature reserve. This research was aimed at determining the diversity of species of aquatic insects in several springs around MTNR.

\section{Material and Method}

\section{Location}

The research was conducted in springs located in Tunua and Fatumnasi villages around TMNR (Picture 1). The separation and identification of insects were made in the Science and Mathematics UPT Laboratory of Widya Mandira Catholic University.

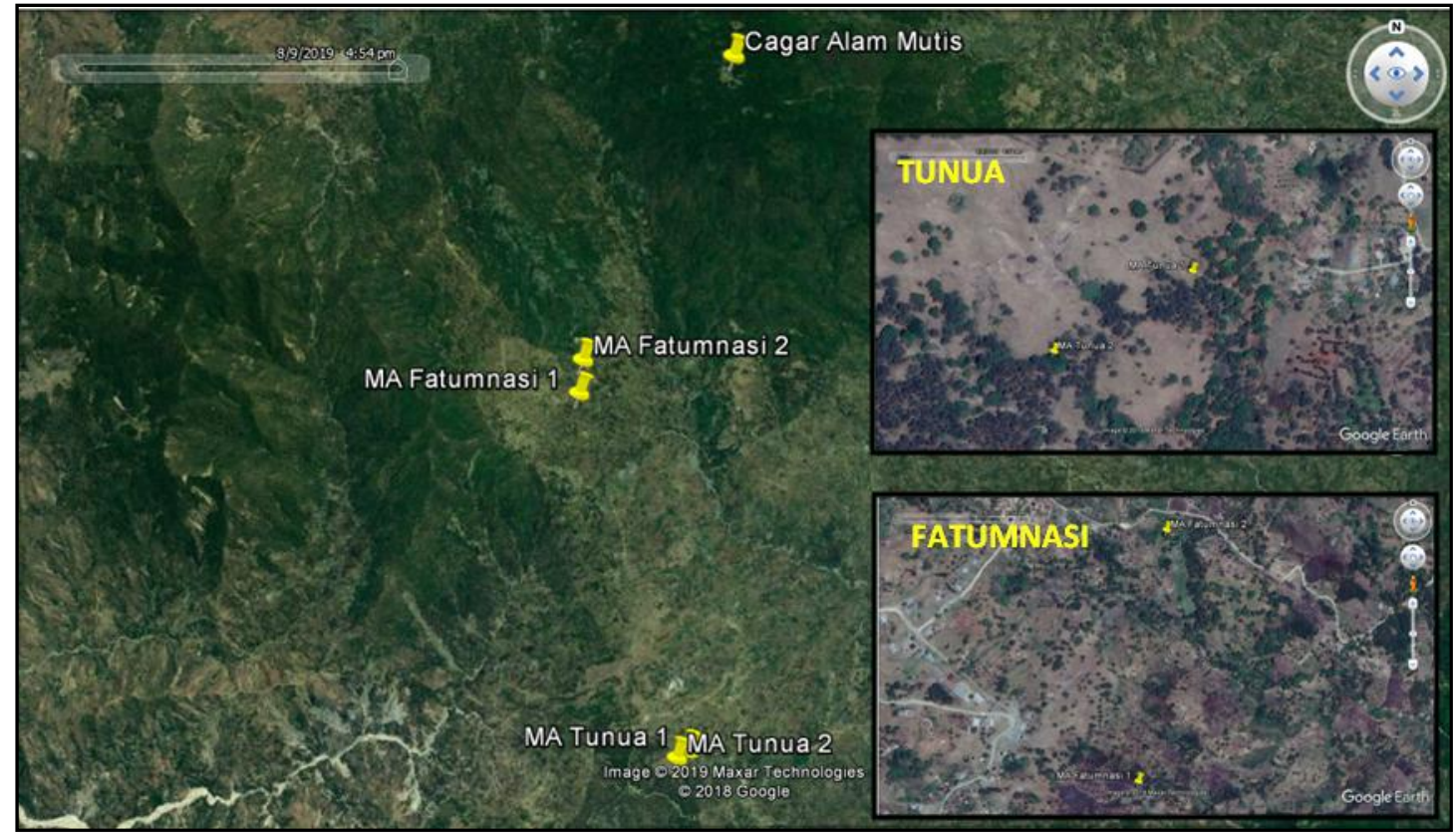

Picture 1. The insect sampling locations of selected springs

Note: MA = Mata air(springs)

\section{Research media}

The media used in this research were the insects caught by hand sorting and yellow-pan trap, detergent for destroying the sample, and $70 \%$ alcohol to attract and preserve the insects. This research also used a soil tester measure soil $\mathrm{pH}$ and temperature, GPS to determine the coordinates of locations, label paper for labeling insect specimens, and writing instruments.

\section{Sample collection technique}

The insect sampling collection was through yellow pan trap and hand sorting. The yellow pan trap was the fast and easy way to catch the insects
(Semiun, et al., 2020). The yellow pan trap was a yellow plastic bottle with a $6.5 \mathrm{~cm}$ diameter. The yellow plan trap was filled with aqua solution, $70 \%$ alcohol, and detergent so the trapped insects didn't fly and die. The trap was set starting from 08.00 a.m. for 24 hours. The insect's environmental factor measurement was done by measuring soil $\mathrm{pH}$ and soil temperature. Those abiotic factors were measured by using a soil tester.

\section{The separation and identification of insects}

The caught insects were separated and identified based on morphospecies in the Science and Mathematics UPT Laboratory of Widya 
Mandira Catholic University. The identification process was done by using identification guidance books (Borror et al., 1992; Borror \& White, 1970; Siwi, 2006) and internet browsing on the related websites.

\section{Data Analysis}

The data obtained in this study were variable data on insect quality and abiotic factors tabulated using Microsoft excel 2010. Data analysis was carried out quantitatively to determine the diversity of spring insects. The obtained and identified insects were grouped based on their families and a direct count of the individuals collected was carried out. These data were then analyzed to find diversity index, species richness index, dominance index, and evenness index referring to Semiun \& Stanis (2016).

\section{Diversity Index}

The diversity index was calculated from the number of individual numbers or the frequency of the entire sample. The equation was then calculated by using the Shannon-Wiener Index.

Note:

$$
\mathrm{H}^{\prime}=-\Sigma \text { pi ln pi; pi= ni/N }
$$

$\mathrm{H}^{\prime}=$ Diversity Index

$\mathrm{Pi}=$ Proportion of number of individuals of type to- $i$ with the total number of all types of individuals

$\mathrm{ni} \quad=$ Number of individuals of $-i$ species

$\mathrm{N}=$ Total number of all individuals

\section{Species Richness (RI)}

The species richness was determined by using the Margalleft index (RI). The Margalleft index (RI) is an index that shows the richness of the types of a community, where the magnitude of this value is influenced by the number of types and individuals in that area. The magnitude of $\mathrm{RI}<3,5$ indicates that species richness is low, $\mathrm{RI}=3,5-5,0$ indicates that species richness is classified as medium and $\mathrm{R}>5,0$ reveals that the richness index is high.

Note:

$$
\mathrm{R} 1=\frac{\mathrm{S}-1}{\ln \mathrm{N}}
$$

$\mathrm{R} 1=$ Index of species richness

$$
\mathrm{S} \quad=\text { Number of species }\left(\mathrm{n}_{1}, \mathrm{n}_{2}, \mathrm{n}_{3}, \ldots\right)
$$

$\mathrm{N} \quad=$ Number of individuals

Simpson's Dominant Index (D)

The calculation of the dominance index uses the formula (Ludwig \& Reynold, 1988 in Taradipha, 2018):

$$
\begin{gathered}
\mathrm{D}=\Sigma \mathrm{Pi}^{2} \\
\mathrm{Pi}=\frac{n i}{N}
\end{gathered}
$$

Notes:

ni: number of particular species

$\mathrm{N}$ : Total number of species

D : Dominance Index

Species dominance has a dominance index value of $0,00<\mathrm{D}<0,50$ indicating low dominance, $0,05<\mathrm{D}$ $<0,75$ showing moderate dominance, and $0.75<\mathrm{D}$ $<1.00$ indicating high dominance.

\section{Species evenness}

The Shannon (E) was used to determine the evenness level of species (Magurran, 2004) According to Ludwig \& Reynolds (1988), the evenness value ranged from $0-1$. The value of $E$ that is close to 0 indicates that a species is dominant in the community. If the value of $\mathrm{E}$ approaches 1, it reveals that all types have almost the same degree of evenness as follows:

$$
E=\frac{\mathrm{H}^{\prime}}{\ln (\mathrm{S})}
$$

Note:

$\mathrm{H}^{\prime}$ = Diversity Index

$\mathrm{S}=$ Number of species

\section{Result and Discussion}

\section{The Diversity of Spring Insects in Tunua and Fatumnasi Villages}

16 species from 14 families and five insects' ordo with 36 total number of individuals were found in the spring of Tunua and Fatumnasi village (Table 1). These families include Gryllidae, Gryllotalpidae, Tetrigidae, Formicidae, Pompilidae, Apidae, Ochteridae, Veliidae, Hydrometridae, Nepidae, Coenagrionidae, 
Libellulidae, Carabidae, and Coccinellidae. Species diversity is the number of species found in a community. Based on the results of the diversity index calculation, a total value of 2.12 is obtained and classified as a medium category $\left(\mathrm{H}^{\prime}=1-3\right)$.

Table 1. The Diversity of Spring Insects in Tunua and Fatumnasi Village

\begin{tabular}{lllrlr}
\hline \multicolumn{1}{c}{ Order } & \multicolumn{1}{c}{ Family } & \multicolumn{1}{c}{ Species } & $\sum$ & \multicolumn{1}{c}{$\mathbf{H}^{\prime}$} \\
\hline Orthoptera & Gryllidae & Tarbinskiellus portentosus & 1 & 0.099542 \\
Orthoptera & Gryllidae & Acheta sp. & 4 & 0.244136 \\
Orthoptera & Gryllotalpidae & Gryllotalpidae orientalis & 1 & 0.099542 \\
Orthoptera & Tetrigidae & Belalang coklat kecil & 1 & 0.099542 \\
Hymenoptera & Formicidae & Iridomyrmex sp. & 16 & 0.360413 \\
Hymenoptera & Pompilidae & Pepsis sp. & 1 & 0.099542 \\
Hymenoptera & Apidae & Apis sp. & 1 & 0.099542 \\
Hemiptera & Ochteridae & Kepik hitam kecil & 1 & 0.099542 \\
Hemiptera & Veliidae & Microvelia sp. & 1 & 0.099542 \\
Hemiptera & Hydrometridae & Hydrometra sp. & 2 & 0.160576 \\
Hemiptera & Nepidae & Nepa sp. & 1 & 0.099542 \\
Odonata & Coenagrionidae & Ischnura senegalensis & 2 & 0.160576 \\
Odonata & Libellulidae & Orthetrum sabina & 1 & 0.099542 \\
Odonata & Libellulidae & Crocotermis sp. & 1 & 0.099542 \\
Coleoptera & Carabidae & Dicaelus sp. & 1 & 0.099542 \\
Coleoptera & Coccinellidae & Paranaemia vittigera & 1 & 0.099542 \\
& & & $\mathbf{3 6}$ & $\mathbf{2 . 1 2}$ \\
\hline
\end{tabular}

Note: $H^{\prime}=$ Diversity Index Shannon-Wiener

Orthoptera and Hemipthera ordo was found with the highest number of species, i.e., four species each. The Orthoptera ordo found included Tarbinskiellus portentosus, Acheta sp., Gryllotalpidae orientalis, and family of Tetrigidae (small brown grasshoppers). Those four types of insects were crickets and grasshoppers. Crickets are insects that reach around 3000 species which are widely spread (AlSaffar \& Augul, 2018). Insects included in this group are generally phytophagous thus disturbing the plants, especially herbaceous plants (Sultana et al., 2016). Grasshopper is a type of insect from Ortophthera ordo with many species reaching 20.000 (Prakoso, 2017). Some members of Ortophera are known as plant eaters. Still, some of them act as decomposer, predators of other insects, and pets. Therefore they are potentials to be used as indicators of environmental quality (Semiun \& Mamulak, 2019).

The found Hemiptera ordo included the families of Ochteridae (Small black ladybugs),
Microvelia sp., Hydrometra sp., and Nepa sp.Ochteridae is a semi-aquatic insect species, lives in the quiet coastal area, especially on mud and dunes. Ochterida insects are predators, which mostly eat fly larva (Diptera), springtails (Collembola), and aphids. Ochterid insects are very vulnerable to habitat disturbance thus they can be used as bioindicators of water quality. The water quality is quite good if these insects are living in it. Microvelia sp. belongs to the family Veliidae. This family is globally distributed and is a group of semi-aquatic predatory insects. Currently, about 60 genus and more than 960 species of Veliidae are known (Moreira \& Barbosa, 2011). Hydrometra $\mathrm{sp}$. is a type of aquatic insect distributed throughout the country. The Hydrometra genus measures 9-12 $\mathrm{mm}$. It has a very long and slender body, legs, and head, its eyes are bulging and located at the back of the middle head area (buggide.net, August 2019). The Hemiptera ordo is the type of Nepa sp. The habitat of this insect is in shallow freshwater, and 
it is also found submerged in vegetation (Cowan \& Cowan, 2016).

Iridomyrmex sp. is the highest number of species found with a total of 16 individuals. This species is a type of black ant which widely spread and is most commonly found in semi-arid and arid climates. The habitat of this species is generally in the soil, and also be found in open places, under the stone, barks, and woods (Hetterick \& Shattuck, 2011). The research conducted by Azmi et al., (2019) found that ant group were mostly found in the forest. The abundance of ants is influenced by the type of vegetation, soil structure, and land-use patterns. The species diversity index in one place differs from another depending on the biotic and abiotic factors. The observations (Table 1) show that the diversity index of spring insects is moderate $\left(\mathrm{H}^{\prime}=1-3\right)$, which indicates that the number of individuals is not diverse. A community is said to have high species diversity if the community is composed of many species with an abundance of species the same or almost the same. Conversely, if the community is composed of very few species, the species diversity is low (Surani et al., 2018), making the community unstable (Chenchouni, 2015).

\section{Species Richness, dominance Index, evenness Index}

Species richness is determined by using the Margalleft Richness Index which is influenced by the number of species and the number of individuals in a habitat. The magnitude of R1 $<3.5$ indicates low species richness, $\mathrm{R} 1=3.5-5.0$ indicates medium species richness and $\mathrm{R}>5.0$ is high. The index value of spring insect species richness was found to be 4.19. Based on the criteria, the wealth index of spring insects found was classified as moderate (Table 2).

Species dominance has a dominance index value of $0.00<\mathrm{D}<0.50$ indicating low dominance, $0.05<\mathrm{D}<0.75$ indicating moderate dominance, and $0.75<\mathrm{D}<1.00$ indicating high dominance. The results of the calculation of the dominance index of spring insect species were 0.23. Based on the criteria, this result indicates low dominance or no dominant insect species.

Tabel 2. Species Richness, Dominance index, and Evenness Index of Insects in Tunua and Fatumnasi Springs

\begin{tabular}{lcc}
\hline \multicolumn{1}{c}{ Indeks } & Value & Category \\
\hline Species Richness (R1) & 4,19 & Moderate \\
Dominance index (D) & 0,23 & Low \\
Evenness Index (E) & 0,76 & Stable community \\
\hline
\end{tabular}

The evenness value ranges from 0 to 1 (Ludwig \& Reynolds, 1988). E value that is close to 0 indicates that a species becomes dominant in the community. If the value of $\mathrm{E}$ is close to 1 it shows that all species have almost the same level of evenness. The results of the calculation of the evenness index $(\mathrm{E})$ of spring insects were found to be 0.76 (E close to 1). These results indicated that the evenness of species was almost the same and no species dominated. Species richness of spring insects refers to the number of species found in an ecosystem. The total number of species in a community depends on the sample size and time (Ludwig \& Reynold, 1988). Based on the criteria of Ludwig and Reynolds (1988), the species richness of spring insects is moderate with a value of 4.19 ( $\mathrm{R} 1=3.5-5.0)$. The species richness of insects in springs can be determined by the abundance of food and other resources found in the spring.

The analysis results of spring insects' species evenness index (E) are close to value 1. It interpreted that each type of insect gets the same opportunity in a community (Rozzhiansha et al., 2019). However, suppose the value of the species evenness index is close to value 0 . In that case, it indicates that the composition of insect species is not evenly distributed due to the dominating species, so community instability. In this study, there were no dominant spring insect species $(D=$ $0.23 /$ low) thus that the spring habitat in this research was relatively stable. The springs located in Tunua and Fatumnasi villages have unique characteristics. Tunua village has a lower elevation than Fatumnasi village with an average of $1261 \mathrm{~m}$ above sea level, while Casuarina equisetifolia 
spruce trees dominated Tunua village spring. It is commonly called mountain pine. There are also other plants such as banyan, palm, and bamboo.

Meanwhile, in Fatumnasi village the character of spring plants varies from cultivated plants such as mango, koesambi, mountain pine, атрири, and banyan. Human activities have influenced Fatumnasi village. The community ties cattle near the spring, so there is a lot of cow dung. In addition, there are washing and farming activities. The community grows carrots, sweet potatoes, rice near the spring. The measured abiotic factor conditions include soil $\mathrm{pH}$ and temperature. The average $\mathrm{pH}$ in Tunua Village was 6.5 (Acid), while in Fatumnasi Village the $\mathrm{pH}$ was 7 (neutral). The $\mathrm{pH}$ range supports the growth and development of spring insects. The temperature range of the Tunua springs is $18-21{ }^{\circ} \mathrm{C}$, while Fatumnasi is $18-19{ }^{\circ} \mathrm{C}$. The effective temperature ranges for insects to live are as follows: minimum temperature $15^{\circ} \mathrm{C}$, optimum temperature $25^{\circ} \mathrm{C}$, and maximum temperature $45^{\circ} \mathrm{C}$. Insects have a certain temperature range in which they can live. Outside this range, insects will die of cold and overheating due to disruption of physiological processes.

\section{Conclusion}

The spring insect families found in Tunua and Fatumnasi villages around the Mutis nature reserve include Gryllidae, Gryllotalpidae, Tetrigidae, Formicidae, Pompilidae, Apidae, Ochteridae, Veliidae, Hydrometridae, Nepidae, Coenagrionidae, Libellulidae, Carabidae, and Coccinellidae. The diversity of spring insects found was categorized as moderate $\left(H^{\prime}=1-3\right)$, with a value of 2.12. The species richness (richness index) of spring insects was classified as moderate $(\mathrm{R} 1=3.5-5.0)$, with a value of 4.19 . There were no dominant insect species $(\mathrm{D}=0.23)$, with almost the same level of evenness $(E=0.76)$.

\section{Acknoeledgements}

Thank you to the rector of Widya Mandira Catholic University through the LPPM that has funded this research. To Mr. Kalvin Sa'u and his family who has accommodated the research team.

\section{Refferences}

Al-Saffar, H., \& Augul, R.S. (2018). Survey of field crickets (Orthoptera, Grylidae) in different regions of Iraq.Advances in Bioresearch, 9 (3), 168-173. DOI: 10.15515/abr.0976-4585.9.3.168173

Azmi, A., Saaidin, M. F. M., Hussain, M. H. \& Hatta, M. F. M. (2019). A survey on diversity of insects in Pulau Sibu, Johor.Malayan Nature Journal, 71 (3), 349 359.

Borror, D., J. \& White, R. E. (1970). A Field Guide to Insect Ameraca north of Mexico. New York: Houghton Mifflin Company.

Borror, D. J., Triplehorn, C.A. \& JohnsonN. F. (1992). Pengenalan Pelajaran Serangga Edisi Keenam. Yogyakarta: Gadjah Mada University Press..

Chenchouni, H., Menasria, T., Neffar, S., Chafaa, Bradai, L, Chaibi, R., Mekahlia,MN., Bendjoudi, D. \& A. Si Bachir (2015). Spatiotemporal diversity, structure and trophic guilds of insect assemblages in a semi-arid Sabkha ecosystem.PeerJ, 3, 850860. https://doi.org/10.7717/peerj.860

Cowan, P. J. \& Cowan, E. M. (2016). The Arabian waterscorpion (Insecta: Heteroptera: Nepidae) can fly. Tribulus, 24, 144-145. https://www.researchgate.net/publication/3 $\underline{14078655}$

Hasan, I., Haloi, D. J., Chetri S., \& Begum, S. (2016). Biodiversity of aquatic insect population in three permanent ponds of Guwahati, Assam, India. International Journal of Fisheries and Aquatic Studies, 4 (6), 271-275.

DOI: $\underline{\text { http://dx.doi.org/10.22271/fish }}$

Heterick, B. E. \& Shattuck, S. (2011). Revision of the ant genus Iridomyrmex (Hymenoptera: Formicidae). New Zealand: Magnolia Press.

Ludwig, J. A. \& Reynolds, J. F. 1988.Statistical Ecology: A Primer methods and computing. New York: JohnWiley \& Sons. 
Mohd, R. Z., Fauziah, I., Ismail, R., Mohd, H. S., Fairuz, K., Hazmi, A. D. \& Salmah M. R. (2012). Diversity of aquatic insects in Keniam river, National Park, Pahang, Malaysia. Asian Journal of Agriculture and Rural Development, 2 (3), 312-328. DOI: 10.22004/ag.econ.197977

Moreira, F. F. F. \& Barbosa, J. F. (2011). The veliidae (hemiptera: heteroptera: gerromorpha) from Sa o Paulo state, Brazil: new species, descriptionof the male of microvelia ioana Drake \& Hottes, 1952, and synonymical and distributional notes. Int. J. Lim., $\quad 47, \quad$ 297-311. DOI: 10.1051/limn/2011010

Nuraeni, S., Khusna, A. \& Sadapotto, A. (2019). Keanekaragaman serangga air dan biomonitoring berbasis indeks famili biotik.Penelitian Hutan dan Konservasi Alam, $\quad 16 \quad$ (2), 147 157. https://doi.org/10.20886/jphka.2019.16 $\underline{.2 .147-157}$

Pakulnicka, J., Buczy’nski, P., Dabkowski, P., Buczy'nska, E., Stepie'n, E., Stryjecki, R., Szlauer-Łukaszewska,A. \& Zawal, A. (2016). Aquatic beetles (Coleoptera) in springs of a small lowland river: habitat factors vs. landscape factors. Knowledge \& Management of Aquatic Ecosystems. 417 (29), 1-13. DOI: 10.1051/kmae/2016016

Popoola, K. O. K. \& Otalekor, A. (2011). Analysis of aquatic insects' communities of Awba reservoir and its physico-chemical properties.Research Journal of Environmental and Earth Science, 3 (4), 422-428.

Prakoso, B. (2017). Biodiversitas belalang (Acrididae: Ordo Orthoptera) pada agroekosistem (Zea mays L.) dan ekosistem hutan tanaman di kebun raya baturaden, Banyumas. Biosfera, 34 (2), 80-88. DOI:0.20884/1.mib.2017.34.2.490

Rozziansha, T. A. P., Prasetyo, A. E., Pradana, M. G. \& Susanto, A. (2019). Keanekaragaman serangga pada ekosistem kelapa sawit terpapar insektisida dalam jangka panjang.J. Pen. Kelapa Sawit, 27 (3), 177-186. https://doi.org/10.22302/iopri.jur.jpks.v27i3 .87

Semiun, C. G. \& Mamulak, Y. I. (2019). Keanekaragaman jenis belalang (ordo orthoptera) di pertanian kacang hijau(Vigna radiate L.) desa Manusak kabupaten Kupang.Stigma, $12 \quad$ (2), 66-70. https://doi.org/10.36456/stigma.12.02.2047. $\underline{66-70}$

Semiun, C. G., Lengur, E. R. A. \& Duhan, G. U. U B. (2020). Insect diversity profile of mangrove ecosystem in Menipo Nature Tourism Park, East Amarasi, East Nusa Tenggara.IOP Conference Series: Materials Science and Engineering, 823, pp. 1-9.

Siwi, S. (2006). Kunci Detereminasi Serangga. Yogyakarta: Kanisius.

Sultana, R., Dayo, M. S., Wagan, M. S. \& Lal, M. (2016). The thar crickets (Orthoptera: Gryllidae). Sindh University Research Journal (Science Series), 48 (3), 647-650.

Surani, S., Yani, A. Y. \& Anita,R. P. (2018). Keanekaragaman dan Kelimpahan Arthropoda Predator Di Bawah Tegakan Tanaman Kayu Putih Umur 2 Tahun Di KHDTK Kemampo.Prossiding Seminar Nasional Sains dan Teknologi Terapan. FST UIN Raden Fateh Palembang, 148-152. 